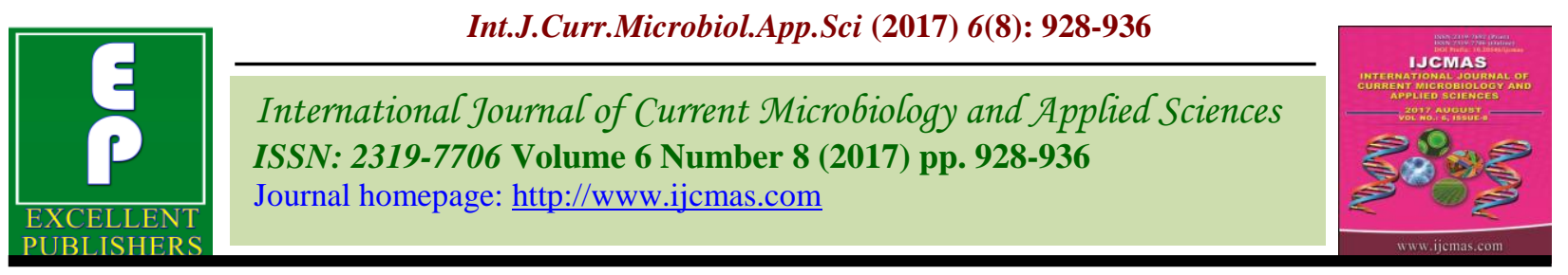

Original Research Article

https://doi.org/10.20546/ijcmas.2017.608.114

\title{
A Study on the Quality Changes of Taktir Fruits (Garcinia lancifolia. Roxb) in Different Packages during Storage
}

\author{
T. Angami ${ }^{1}$, S.R. Assumi ${ }^{2}$, S. Baruah ${ }^{1}$, A. Sen ${ }^{1}$, B. Bam ${ }^{1}$, A. Khatoon', \\ B. Gurung ${ }^{3}$ and H. Kalita ${ }^{1}$ \\ ${ }^{1}$ ICAR Research Complex for NEH Region, Arunachal Pradesh Centre, \\ Basar - 791 101, West Siang district, India \\ ${ }^{2}$ ICAR Research Complex for NEH Region, Umiam - 793 103, Meghalaya, India \\ ${ }^{3}$ Division of Statistical Genetics, IASRI, New Delhi - 110 012, India \\ *Corresponding author
}

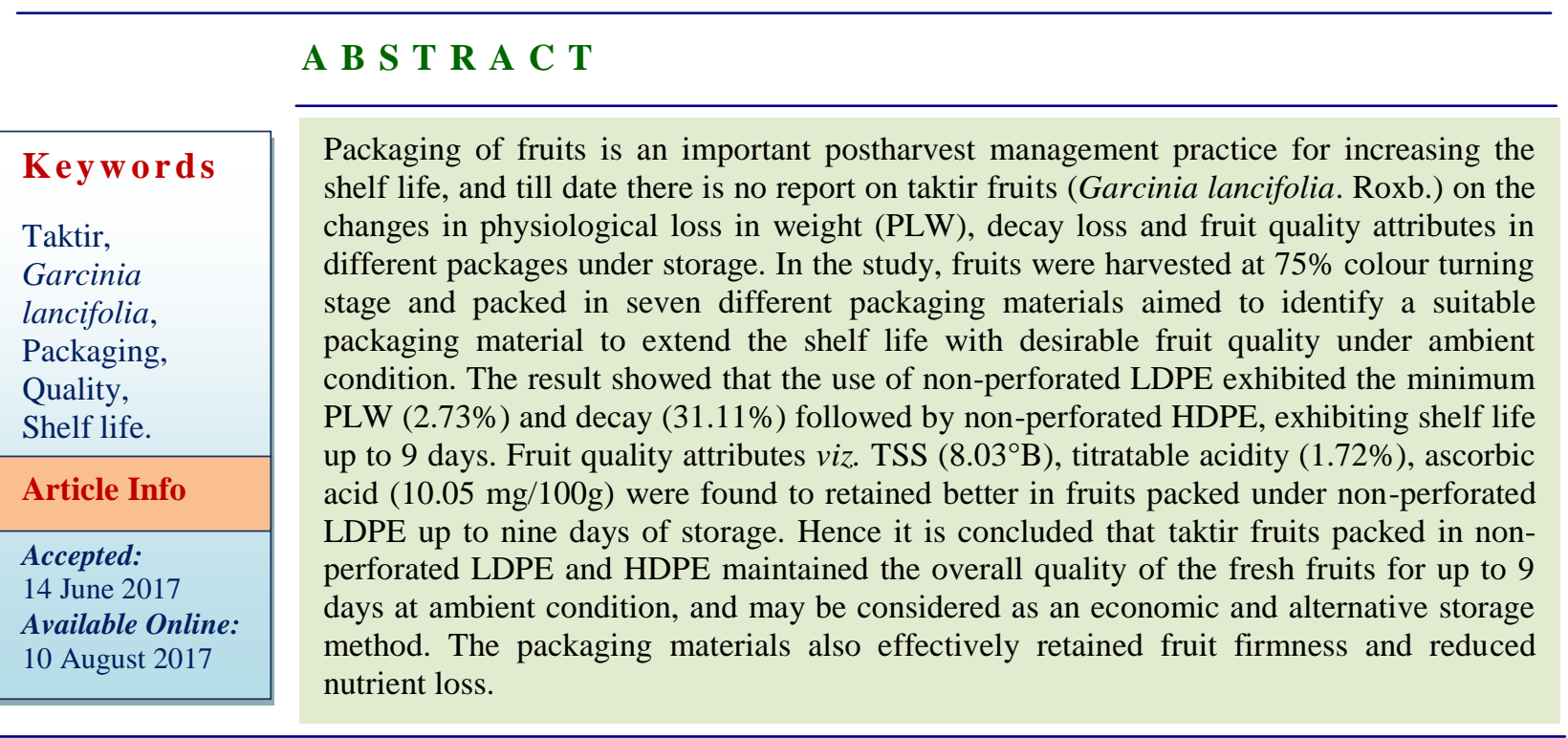

\section{Introduction}

Taktir (Garcinia lancifolia. Roxb) fruit belonging to the family Clusiaceae, is one of the indigenous fruits trees found in the state of Arunachal Pradesh, which is largely consumed by the rural and tribal masses. It is an ever green glabrous shrub, bearing in clusters and grows up to a height of 5 metres commonly under evergreen dense forest at an altitude range of 515 to $750 \mathrm{~m}$ above mean sea level (Kumar et al., 2014). Fruits mature during the months of April to May, which tastes tangy when raw and become sweet on maturity attaining an attractive tomato red colour when fully ripe. Due to its high perishable nature, fruits exhibit shelf life of only 3-5 days at room temperature $\left(25-30^{\circ} \mathrm{C}\right)$ without packaging and besides, lack of awareness on handling practices and packaging materials adds to postharvest loss. Packaging material is vital in extending the shelf life of fruits, and this will make fruits available for a longer period of time and help 
the growers to fetch better price. Singh et al., (2008) reported the use of high-density polyethylene pouches to extend shelf life of strawberry up to six days. Similarly, shelf life of passion fruit increased upto five weeks when the fruits were packed in polyethylene terephthalate packaging (Patel et al., 2009). Besides, packaging aids in retention of nutritive values over an extended period of time (Deka et al., 2013). Keeping these facts in view, the present investigation was carried out to identify a suitable packaging material with an objective to extend the shelf life of the quality taktir fruits under ambient condition.

\section{Materials and Methods}

Uniform sized taktir fruits at 75 percent colour turning stage were collected from ICAR Research Farm, Gori, Basar, Arunachal Pradesh, sorted and washed thoroughly with water to remove dirt from surface and dried of remaining moisture. The fruits were then packed in seven types of packaging materials viz. $\mathrm{T}_{1}$ : Bamboo basket, $\mathrm{T}_{2}$ : LDPE $(0.025$ $\mathrm{mm}$, Non-perforated), $\mathrm{T}_{3}$ : HDPE $(0.025 \mathrm{~mm}$, Non-perforated), $\mathrm{T}_{4}$ : LDPE $(0.025 \mathrm{~mm}$, $0.01 \%$ Perforation), $\mathrm{T}_{5}$ : HDPE $(0.025 \mathrm{~mm}$, $0.01 \%$ perforation), $\mathrm{T}_{6}$ : Leaf (Phrynium pubinerve) and $\mathrm{T}_{7}$ : $\mathrm{CFB}$ (6 breathing holes, 2 $\mathrm{cm}$ diameter). The packed fruits were stored at ambient condition $\left(25 \pm 2{ }^{\circ} \mathrm{C}\right.$ and $80 \pm 5 \%$ $\mathrm{RH})$ and data was recorded in triplicates at 3 days interval for up to 9 days following a completely randomised design. An electronic weighing balance (with accuracy of $0.01 \mathrm{~g}$ ) was used to measure the weight of fruits. The PLW was calculated as the difference between the initial weight and the weight at the time of measurement, and expressed as percentage ( $\%$ of initial weight). Decay loss was calculated from number of fruits infected on days of observation to the number of fruits initially taken (Ranganna, 1997).

Decay loss $(\%)=\underline{\text { Total nos. } \text { of fruits taken }- \text { Total nos. of uninfected fruits }} \times 100$

\section{Nos. of fruits taken}

As far as biochemical analysis is concerned, total soluble solids (TSS) was determined with Erma hand refractometer $\left(0-32^{\circ}\right.$ Brix $)$ where a drop of the juice was used with a calibrated digital refractometer. Titratable acidity was estimated by titrating against $0.1 \mathrm{~N}$ sodium hydroxide using phenolphthalein as indicator (AOAC, 2000). Ascorbic acid content was determined by titrating sample filtrate in $4 \%$ oxalic acid using 2, 6Dichlorophenolindophenol dye to a pink point and expressed as mg/100g (AOAC, 2005). Total sugar and $\beta$-Carotene were estimated by Anthrone (Sadasivam et al., 2005) and colorimetric methods (Srivastava and Kumar, 2002) respectively. Anthocyanin content was estimated as described by (Harborne, 1973) and expressed as $\mathrm{mg} / 100 \mathrm{~g}$ fruit weight, where the blended sample of $10 \mathrm{~g}$ was mixed with 10 $\mathrm{ml}$ of ethanol-hydrochloric acid mixture $\left(95 \% \mathrm{C}_{2} \mathrm{H}_{5} \mathrm{OH}\right.$ and $1.5 \mathrm{~N} \mathrm{HCl}$ in the ratio of $85: 15)$, transferred into a $100 \mathrm{ml}$ volumetric flask and kept overnight at $4^{\circ} \mathrm{C}$, filtered through Whatman No. 1 and measured at 535 $\mathrm{nm}$ in spectrophotometer meanwhile the shelf life of packed fruits was determined based on visual and textural qualities of fruits by constituting a panel of five members.

Mean data of two years was subjected to analysis of variance (ANOVA) with packaging materials and storage time as the sources of variation, and mean comparison was performed using the Tukey's Honest Significant Difference (HSD) test. A difference was considered statistically significant when $p$-value was less than 0.05 $(p<0.05)$. All analysis was performed with 
SAS 9.3(TS1MO) software package developed by Statistical Analysis System Institute (2000).

\section{Results and Discussion}

PLW of taktir fruits stored in different packages indicate that there was gradual weight loss in all the treatments (Fig. 1). This could be due to transpiration and respiration resulting in continuous loss of moisture (Nath et al., 2012). Maximum weight loss (15.85\%) was recorded in treatment $\mathrm{T}_{1}$ followed by $\mathrm{T}_{6}$ $(15.66 \%)$ and $\mathrm{T}_{7}(11.15 \%)$ on $9^{\text {th }}$ day of storage. However, minimum weight loss $(2.73 \%)$ was observed in treatment $\mathrm{T}_{2}$ followed by $\mathrm{T}_{3}(5.23 \%)$. Minimum weight loss in non-perforated polythene packaged fruits could be due to less availability of oxygen for respiration, which ultimately retarded the rate of respiration and thereby lowering the moisture loss due to transpiration whereas, higher rate of PLW in treatments $\mathrm{T}_{1}, \mathrm{~T}_{6}$ and $\mathrm{T}_{7}$ were probably due to higher moisture loss and increased respiration through uninterrupted atmospheric column and lower relative humidity (Wills et al., 1998). The present findings were in agreement with the previous findings of (Sandhu and Singh, 2000; Baszczyk and Ysiak, 2001; Calvo et al., 2002; Tijskens and Vollebregt, 2003). Fruit decay loss due to rotting increased as the storage period advanced irrespective of treatments (Fig. 2). This might be due to condensation of moisture on the surface of fruits, anaerobic condition, breakdown of enzymes, etc. which aided in multiplication of micro flora. However, minimum cumulative decay loss $(31.11 \%)$ was recorded in treatment $T_{2}$ on $9^{\text {th }}$ day of storage while the maximum decay loss $(48.89 \%)$ was recorded in treatments $\mathrm{T}_{1}$ and $\mathrm{T}_{6}$. Reduced decay loss might be attributed to limited permeability of gases $\left(\mathrm{CO}_{2}\right.$ and $\left.\mathrm{O}_{2}\right)$ and water vapour, which can interplay with physiological processes of fruits (Tijskens and
Vollebregt, 2003; Soliva and Martin, 2003). Our findings were in agreement with the reports of Drake and Gix (2000) and Dou-Shi Juan et al., (2002) on fruits.

Changes in the fruit quality attributes during storage irrespective of treatments like the titratable acidity decreased throughout the storage period (Fig. 3). Minimum acidity $(1.22 \%)$ was recorded in treatment $\mathrm{T}_{1}$ followed by $\mathrm{T}_{6}$ with $(1.25 \%)$ on the last day of storage whereas maximum $(2.17 \%)$ was recorded $\mathrm{T}_{3}$. Higher level of acidity might be due to reduced respiration rate in the later stage of storage as affected by film permeability to atmospheric gas (Nath et al., 2012).

Reduction in acidity during storage might be associated with the conversion of organic acids into sugars and their derivatives, or due to their utilization in respiration (Zerbini, 2002). TSS increased throughout the storage period with maximum $\left(10.07^{\circ} \mathrm{B}\right)$ recorded in fruits packed in bamboo basket $\left(\mathrm{T}_{1}\right)$ and minimum increase $\left(8.03^{\circ} \mathrm{B}\right)$ in treatment $\mathrm{T}_{2}$ on the $9^{\text {th }}$ day of storage (Table 1). The increase in TSS with the advancement of storage might be due to conversion of reserved starch and other polysaccharides to soluble form of sugars (Singh and Narayan, 1999). Slow increment in TSS may be due to production of higher levels of $\mathrm{CO}_{2}$ leading to reduced physiological processes in fruits for slower ripening (Nath et al., 2012). There was a progressive increase in total sugar up to 9 days (Table 1) with the highest $(13.12 \%)$ recorded in treatment $T_{1}$. Total sugar increase during storage may possibly be due to breakdown of complex organic metabolites into simple molecules or, due to hydrolysis of starch into sugars as reported by (Pongener $e t$ al., 2011) and (Kaur et al., 2013). Ascorbic acid content declined in all the treatments during storage (Table 1). 
Table.1 Effect of packaging materials on TSS, total sugars, ascorbic acid, $\beta$-carotene and anthocyanin of Taktir fruit during storage $\left(25 \pm 2^{\circ} \mathrm{C}\right.$ and $\left.80-85 \mathrm{RH}\right)$

\begin{tabular}{|c|c|c|c|c|c|c|c|c|c|c|c|c|c|c|c|}
\hline \multicolumn{15}{|c|}{ Days after storage } & \multirow{3}{*}{$\begin{array}{l}\text { Treat } \\
\text { ments }\end{array}$} \\
\hline \multicolumn{3}{|c|}{ Anthocyanin (mg/100g) } & \multicolumn{3}{|c|}{$\beta$-carotene $(\mu \mathrm{g} / \mathbf{1 0 0 g})$} & \multicolumn{3}{|c|}{ Ascorbic acid (mg/100g) } & \multicolumn{3}{|c|}{ Total sugar (\%) } & \multicolumn{3}{|c|}{ TSS $\left({ }^{\circ} \mathbf{B}\right)$} & \\
\hline 9 & 6 & 3 & 9 & 6 & 3 & 9 & 6 & 3 & 9 & 6 & 3 & 9 & 6 & 3 & \\
\hline $85.24^{\mathrm{A}}$ & $83.91^{\mathrm{BA}}$ & $\underset{\mathrm{K}}{51.91^{\mathrm{IJ}}}$ & $1.69^{\mathrm{A}}$ & $1.22^{\mathrm{ED}}$ & $0.93^{\mathrm{F}}$ & $8.68^{\mathrm{HG}}$ & $9.06^{\mathrm{HGF}}$ & $11.7^{\mathrm{BA}}$ & $13.12^{\mathrm{A}}$ & $9.27^{\mathrm{ED}}$ & $8.38^{\mathrm{E}}$ & $10.07^{\mathrm{A}}$ & $8.50^{\mathrm{BC}}$ & $5.63^{\mathrm{JHI}}$ & $\mathbf{T}_{1}$ \\
\hline$\underset{C}{72.51^{D E}}$ & $66.63^{\mathrm{FEG}}$ & $40.78^{\mathrm{L}}$ & $1.50^{\mathrm{B}}$ & $1.24^{\mathrm{ED}}$ & $0.99^{\mathrm{EF}}$ & $10.05_{\mathrm{CF}}^{\text {EBDG }}$ & $11.11^{\mathrm{BDAC}}$ & $12.46^{\mathrm{A}}$ & $9.25^{\mathrm{ED}}$ & $8.53^{\mathrm{E}}$ & $8.31^{\mathrm{E}}$ & $8.03^{\mathrm{DC}}$ & $\underset{\mathrm{E}}{7.25^{\mathrm{DF}}}$ & $5.00^{\mathrm{A}}$ & $\mathbf{T}_{2}$ \\
\hline$\underset{\mathrm{G}}{67.46^{\mathrm{FE}}}$ & $61.24_{\mathrm{G}}^{\mathrm{FH}}$ & $\underset{\mathrm{KJ}}{49.04^{\mathrm{L}}}$ & $\underset{A}{1.60^{B}}$ & $\frac{1.17^{\mathrm{ED}}}{\mathrm{F}}$ & $0.92^{\mathrm{F}}$ & $\begin{array}{c}9.59^{\mathrm{EHDGC}} \\
\mathrm{F}\end{array}$ & $11.08_{\mathrm{C}}^{\mathrm{EBDA}}$ & $11.21^{\mathrm{BAC}}$ & $9.40^{\mathrm{ED}}$ & $8.51^{\mathrm{E}}$ & $8.50^{\mathrm{E}}$ & $8.50^{\mathrm{BC}}$ & ${ }_{\mathrm{FE}}^{7.13^{\mathrm{DG}}}$ & $5.40^{\mathrm{JI}}$ & $\mathbf{T}_{3}$ \\
\hline$\underset{\mathrm{C}}{79.20^{\mathrm{BA}}}$ & $69.96^{\mathrm{FDE}}$ & $\underset{\mathrm{KJ}}{48.15^{\mathrm{L}}}$ & $\underset{\mathrm{A}}{1.60^{\mathrm{B}}}$ & $1.40^{\mathrm{BD}}$ & $1.15^{\mathrm{ED}}$ & $9.19^{\mathrm{HGF}}$ & $9.36^{\mathrm{EHGF}}$ & $10.23_{\mathrm{CF}}^{\mathrm{EBDG}}$ & $10.40^{\mathrm{BC}}$ & $9.71^{\mathrm{CD}}$ & $9.20^{\mathrm{ED}}$ & $9.27^{\mathrm{BA}}$ & $\underset{\mathrm{E}}{7.50^{\mathrm{DC}}}$ & $6.10_{\mathrm{I}}^{\mathrm{JHGF}}$ & $\mathbf{T}_{4}$ \\
\hline $75.26^{\mathrm{BD}}$ & $60.43^{\mathrm{IHG}}$ & $\underset{K}{43.66^{\mathrm{L}}}$ & ${\underset{A}{A}}^{\mathrm{B}}$ & $1.40^{\mathrm{BD}}$ & $1.25^{\mathrm{ED}}$ & $9.16^{\mathrm{HGF}}$ & $9.40^{\mathrm{EHDGF}}$ & $12.06^{\mathrm{A}}$ & $11.58^{\mathrm{BA}}$ & $11.30^{\mathrm{B}}$ & $\begin{array}{c}10 . \\
65^{\mathrm{BCD}}\end{array}$ & $8.50^{\mathrm{BC}}$ & ${ }_{\mathrm{FE}}^{6.60^{\mathrm{HG}}}$ & $6.03^{\mathrm{JHGI}}$ & $\mathbf{T}_{5}$ \\
\hline $87.26^{\mathrm{A}}$ & $\underset{\mathrm{AC}}{78.58^{\mathrm{BD}}}$ & $\underset{\mathrm{HJ}}{56.46^{\mathrm{I}}}$ & $1.68^{\mathrm{A}}$ & $\begin{array}{c}1.50^{\mathrm{BA}} \\
\mathrm{C}\end{array}$ & $1.36^{\mathrm{BD}}$ & $9.34^{\mathrm{HGF}}$ & $10.24_{\mathrm{CF}}^{\mathrm{EBDG}}$ & $\begin{array}{c}10.73_{\mathrm{CF}}^{\mathrm{EBDA}} \\
\text { (1) }\end{array}$ & $12.11^{\mathrm{BA}}$ & $\underset{A}{11.58^{B}}$ & $8.06^{\mathrm{E}}$ & $9.80^{\mathrm{A}}$ & $\begin{array}{c}7.13^{\mathrm{DG}} \\
\mathrm{FE}\end{array}$ & $5.10^{\mathrm{JI}}$ & $\mathbf{T}_{6}$ \\
\hline $81.40^{\mathrm{BA}}$ & $\underset{\mathrm{C}}{74.09^{\mathrm{DE}}}$ & $\underset{\mathrm{HG}}{59.93^{\mathrm{I}}}$ & ${ }_{A}^{1.58^{B}}$ & $1.57^{\mathrm{BA}}$ & ${ }_{\mathrm{C}}^{1.40^{\mathrm{BD}}}$ & $8.14^{\mathrm{H}}$ & $8.97^{\mathrm{HG}}$ & $12.07^{\mathrm{A}}$ & $11.73^{\mathrm{BA}}$ & $9.25^{\mathrm{ED}}$ & $8.58^{\mathrm{E}}$ & $8.50^{\mathrm{BC}}$ & $\underset{\mathrm{FI}}{6.23^{\mathrm{HG}}}$ & $5.00^{\mathrm{J}}$ & $\mathbf{T}_{7}$ \\
\hline
\end{tabular}

According to HSD Tukey's test, treatment values with different letters are significantly different $(p<0.05)$ during storage $(3,6$ and 9 days). 
Fig.1 Changes in the physiological loss in weight (\%) of taktir fruits in different packaging materials during storage $\left(25 \pm 2^{\circ} \mathrm{C}\right.$ and $\left.80-85 \% \mathrm{RH}\right)$. Standard error of the mean values is indicated by vertical bars

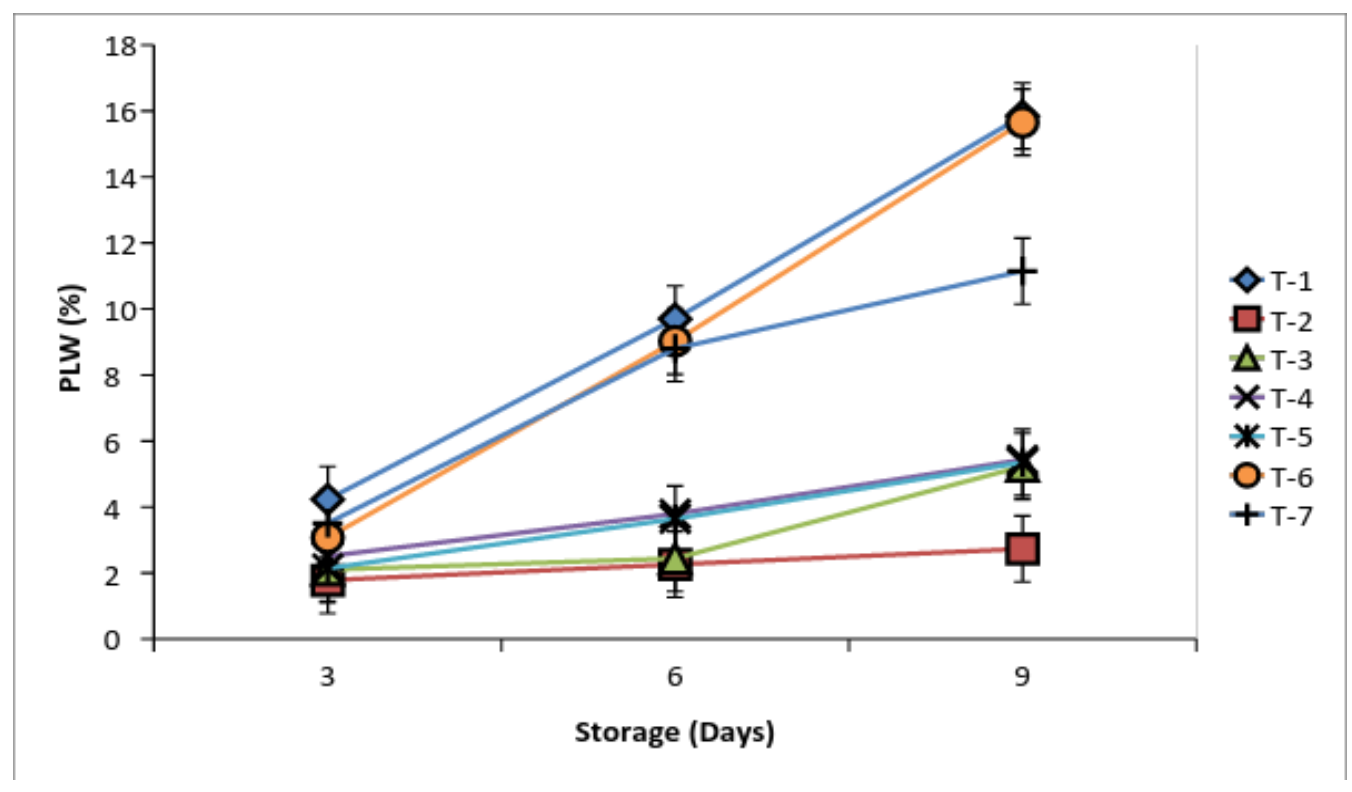

Fig.2 Changes in the decay loss $(\%)$ of taktir fruits in different packaging materials during storage $\left(25 \pm 2^{\circ} \mathrm{C}\right.$ and $\left.80-85 \% \mathrm{RH}\right)$. Standard error of the mean values is indicated by vertical bars

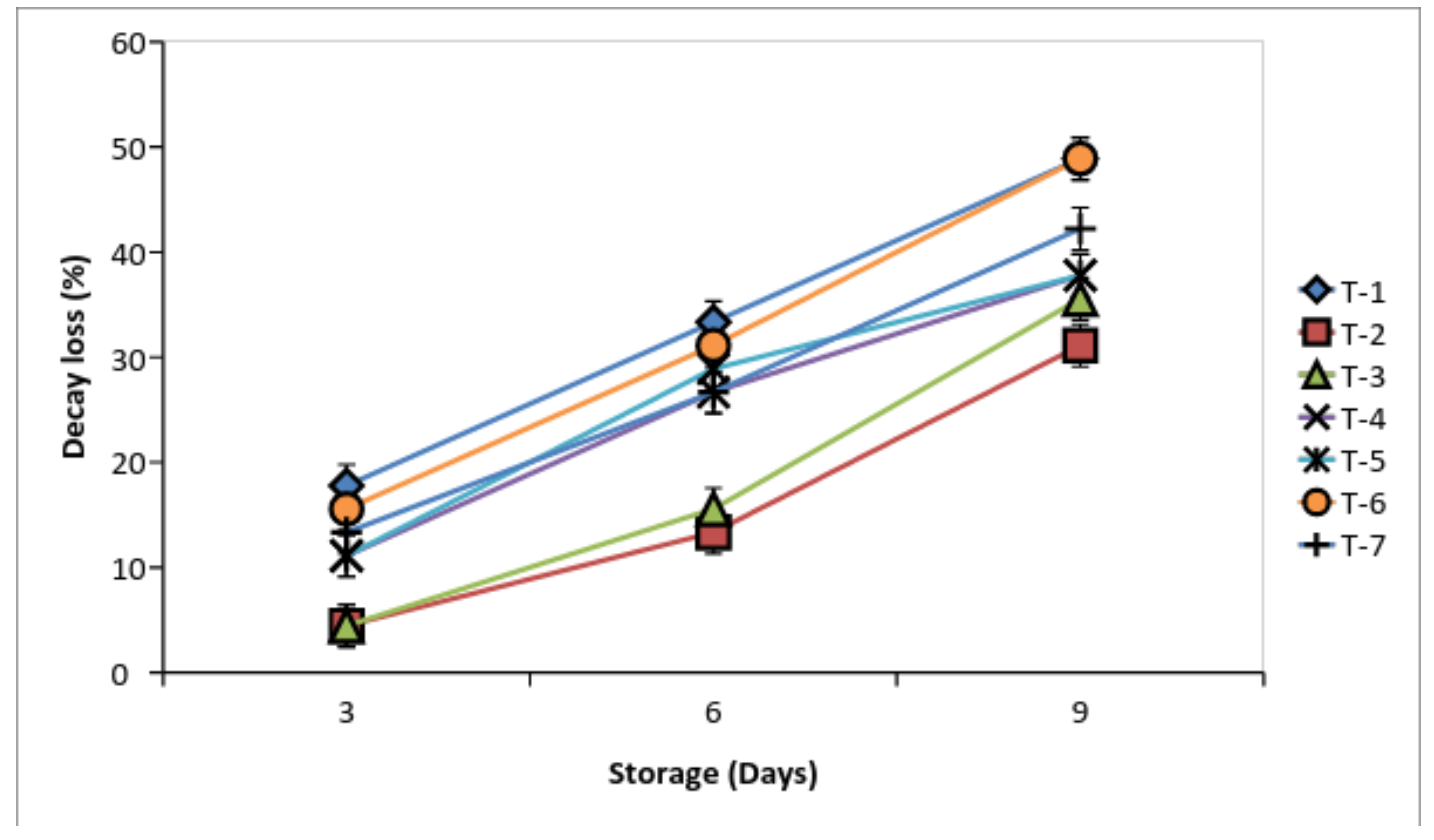


Fig.3 Changes in the titratable acidity (\%) of taktir fruits in different packaging materials during storage $\left(25 \pm 2{ }^{\circ} \mathrm{C}\right.$ and $\left.80-85 \% \mathrm{RH}\right)$. Standard error of the mean values is indicated by vertical bars

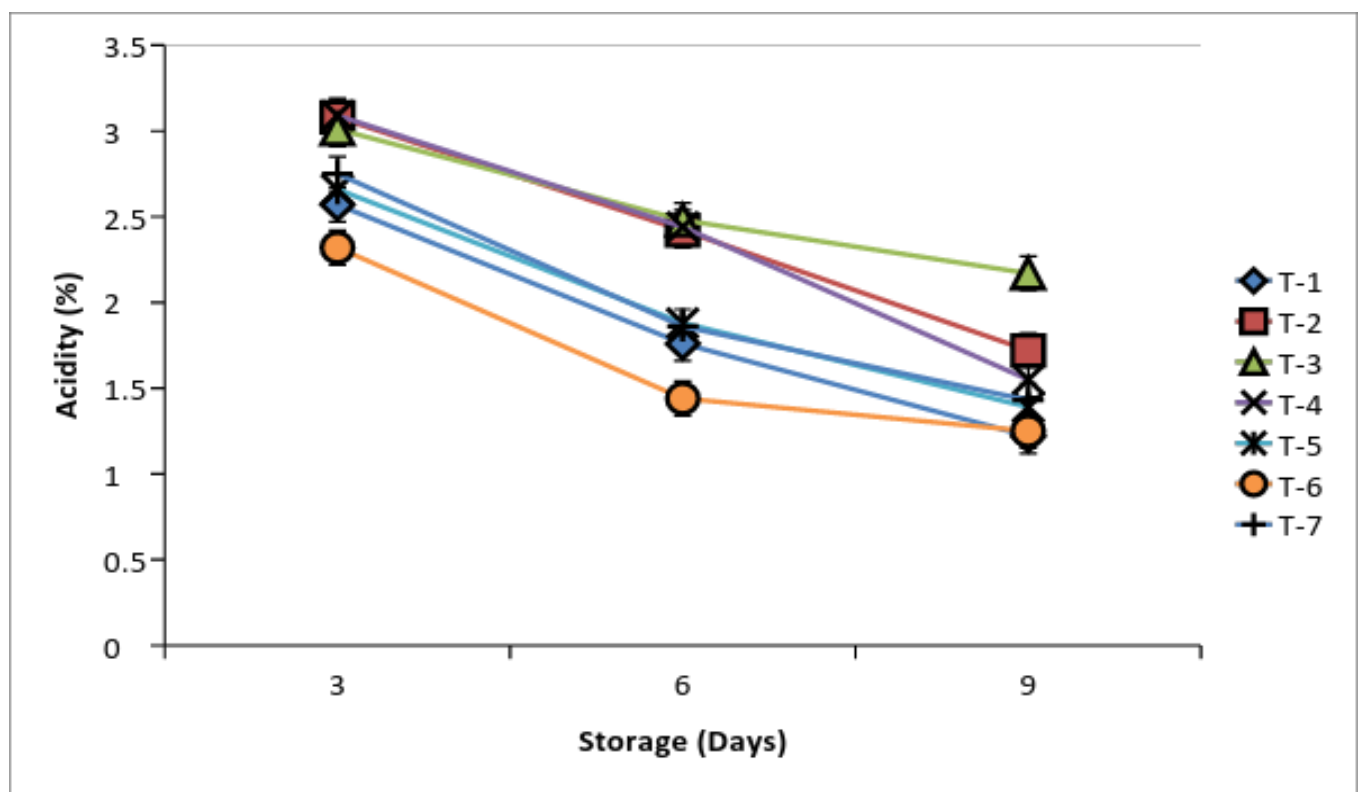

Fig.4 Shelf life (Days) of taktir fruits in different packaging materials during storage $\left(25 \pm 2{ }^{\circ} \mathrm{C}\right.$ and $80-85 \% \mathrm{RH})$. Standard error of the mean values is indicated by vertical bars

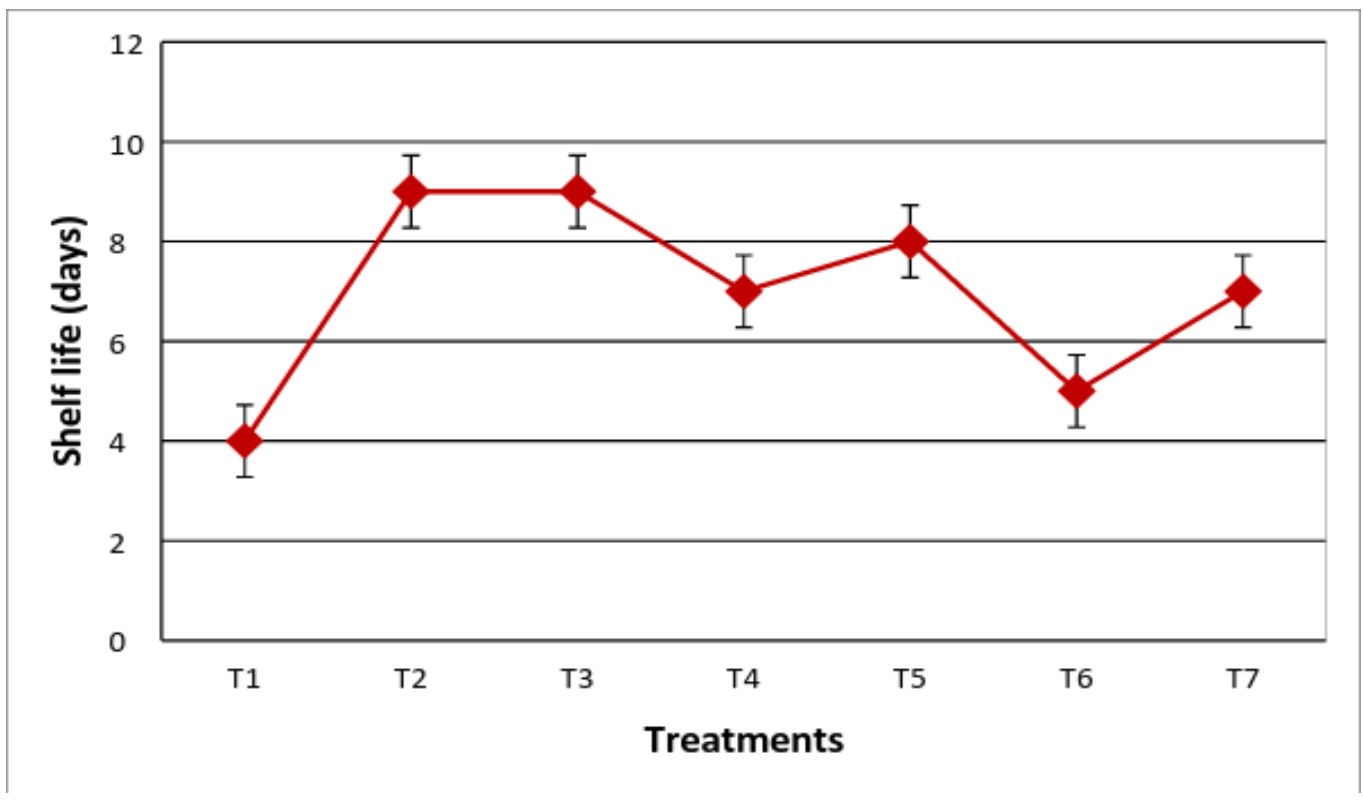


However on the 9th day of storage, fruits packed in LDPE non-perforated $\left(\mathrm{T}_{2}\right)$ retained higher ascorbic acid content $(12.46 \mathrm{mg} / 100 \mathrm{~g})$ as compared to other treatments which ranged from 8.14 to $12.07 \mathrm{mg} / 100 \mathrm{~g}$. Oxidizing enzymes like ascorbic acid oxidase, peroxidase, catalase and polyphenol oxidase contributes in the reduction of ascorbic acid (Mapson, 1970) and activities of oxidizing enzymes might have reduced in LDPE nonperforated packages that resulted in higher retention of ascorbic acid (Nath et al., 2012). Loss in ascorbic acid of kinnow mandarin during storage had been reported by Mahajan et al., (2005). $\beta$-carotene content of taktir fruits increased significantly $(p<0.05)$ with the progress of storage time (Table 1). Maximum increase $(1.69 \mu \mathrm{g} / 100 \mathrm{~g})$ was observed in treatment $T_{1}$ while minimum increase $(1.50 \mu \mathrm{g} / 100 \mathrm{~g})$ was recorded in fruits packed in LDPE non-perforated $\left(\mathrm{T}_{2}\right)$ on the $9^{\text {th }}$ day of storage. Similar trend was reported by Ali et al., (2015) confirming that LDPE non-perforated packaging delayed ripening and carotenoids synthesis. On the other hand, the increase could due to the degradation of chlorophyll and accumulation of carotenoids as the chloroplasts were transformed to chromoplasts (Kader and Grierson, 1978). On the $9^{\text {th }}$ day of storage, maximum anthocyanin content $(87.26 \mathrm{mg} / 100 \mathrm{~g})$ was found in fruits packed in leaf $\left(\mathrm{T}_{6}\right)$ followed by the treatment $\mathrm{T}_{1}(85.24 \mathrm{mg} / 100 \mathrm{~g})$ (Table 1). This increased retention might be due to full colour development by associated enzyme phenylalanine ammonia-lyase (Given et al., 1988) and lower anthocyanin content of $(67.46 \mathrm{mg} / 100 \mathrm{~g})$ and $(72.51 \mathrm{mg} / 100 \mathrm{~g})$ in nonperforated HDPE and LDPE packaging material possibly of more chlorophyll content. Our finding was in agreement with that reported by Ganai et al., (2015) on storage of apple. As far as shelf life is concerned, a gradual decrease in both visual and textural properties of the fruits was observed with the increase in storage time. Highest shelf life of
9 days was found in the fruits packed in both LDPE and HDPE non-perforated $\left(\mathrm{T}_{2}\right.$ and $\left.\mathrm{T}_{3}\right)$ and the lowest in bamboo basket $\left(\mathrm{T}_{1}\right)$ with 4 days (Fig. 4). The extension of shelf life with different packaging materials might be attributed to the modified environment created by accumulation of $\mathrm{CO}_{2}$, depletion of $\mathrm{O}_{2}$ and maintenance of high humidity which helped to maintain turgidity, higher firmness and freshness during storage (Emerald et al., 2001). Similar findings were reported in sapota (Joshua and Sathimurthy, 1993), kiwifruit (Bhushan et al., 2002) and loquat (Amoros et al., 2008). Hence, from this study it is concluded that use of non-perforated LDPE and non-perforated HDPE packaging materials can be considered as an economic and alternative method to extend shelf life of fresh taktir fruits at ambient conditions. These packaging materials besides reducing PLW and decay, also effectively retained fruit firmness, reduced nutrient loss and maintained the overall quality parameters.

\section{References}

Ali, S., Ali, T.M.A., Abbasi, K.S. and Hussain, S. 2015. Influence of packaging material and ethylene scavenger on biochemical composition and enzyme activity of apricot cv.

Habi at ambient storage. Food Sc. Quality Management, 35: 73-82.

Amoros, A., Pretel, M.T., Zapata, P.J., Botella, M.A., Romojaro, F. and Serrano, M. 2008. Use of modified atmosphere packaging with micro perforated polypropylene films to maintain post-harvest loquat fruit quality. Food Sc. Technol. Int., 14(1): 95-103.

Association of Official Analytical Chemists (AOAC). 2000. Official methods of analysis of the AOAC international, $17^{\text {th }}$ edn. Washington, DC.

Association of Official Analytical Chemists 
(AOAC). 2005. Official methods of analysis of the AOAC, $18^{\text {th }}$ edn. Washington, DC.

Baszczyk, J. and Ysiak, G. 2001. Storage properties of Czech pear cultivars 'Erica' and 'Dicolor'. J. Fruit Ornam. Plant Res., 9: 71-76.

Bhushan, S., Triparthy, S.N. and Thakur, N.K. 2002. Effect of different modified atmosphere packaging on the quality of kiwifruit stored at room temperature. $J$. Food Sci. Technol., 39(3): 279-283.

Calvo, G., Salvador, M.E. and Sanchez, E. 2002. Control of superficial scald in 'Beurred'Anjou' pears with low oxygen levels. Acta Hortic., 596: 879-882.

Deka, B.C., Nath, A., Lamare, R.L. and Patel, R.K. 2013. Quality and Shelf-life of Sohshang (Elaeagnus latifolia L.) Fruits in different packages during storage. Indian J. Hill Farming, 26(2): 21-25.

Dou-Shi Juan, Chen-Kun Song, Lu Jun Liang. and Zheng, J.T. 2002. The storability and its regulatory mechanism of Huanghua pear (Pyrus pyrifolia Nakai.) fruit as influenced by postharvest treatments. Agric. Sci. China, 1: 12381245 .

Drake, S.R. and Gix, R.D. 2000. Response of d'Anjou pears to controlled atmosphere storage in elevated temperature and carbon dioxide. Good Fruit Grower, 51: 55-57.

Emerald, F.M.E., Sreenarayanan, V.V. and Parvathy, R. 2001. Physicochemical responses of sapota packed under modified atmosphere. Madras Agric. J., 88(4-6): 271-273.

Ganai, S.A., Ahsan, H., Wani, I.A., Lone, A.A., Mir, S.A. and Wani, S.M. 2015. Colour changes during storage of apple cv. Red Delicious - influence of harvest dates, precooling, calcium chloride and waxing. Int. Food Res. J., 22(1): 196201.

Given, N.K., Venis, M.A. and Grierson, D.
1988. Hormonal regulation of ripening in the strawberry, a non-climacteric fruit. Planta, 174: 402-406.

Harborne, J.B. 1973. Phytochemical Methods. Toppan Co. Ltd., Tokyo, Japan.

Joshua, P. and Sathiamoorthy, S. 1993. Storage of sapota fruits in polyethylene bags. South Indian Hortic., 41: 368-369.

Kader, A.A. and Grierson, D. 1978. Fruit ripening and quality in the tomato crops. JG Atherton and J Rudich Edn. Chapman and Hall Ltd., London, p. 274.

Kaur, K., Dhillon, W.S. and Mahajan, B.V.V. 2013. Effect of different packaging materials and storage intervals on physical and biochemical characteristics of pear. J. of Food Sci. Tech., 50(1): 147-152.

Kumar, P.S., Choudhary, V.K., Devi, P., Kanwat, M. and Sangeetha, M. 2014. Influence of Processing Variables and Storage on the Fruit Drink Developed from Taktir; Wild Fruit of Himalaya. Proc. Natl. Acad. Sci., India, Sect. B Biol. Sci., 85(3): 767-775.

Mahajan, B.V.C., Bhatt A.S. and Sandhu K.S. 2005. Effect of different post-harvest treatments on the storage life of Kinnow mandarin. J. Food Sci. Technol., 42(4): 296- 299.

Mapson, C.W. 1970. Vitamins in fruits: stability of L-ascorbic acid. Biochemistry of fruits and their products. Academic Press, London, pp. 376-387.

Nath, A., Deka, B.C., Singh, A., Patel, R.K., Paul, D., Misra, L.K. and Ojha, H. 2012. Extension of shelf life of pear fruits using different packaging materials. J. Food Sci. Technol., 49(5): 556-563.

Patel, R.K., Singh, A., Yadav, D.S., Bhuyan, M. and Deka B.C. 2009. Waxing, lining and polyethylene packaging on shelf life and juice quality of passion fruit 
during storage. J.Food Sci. Technol., 46(1): 70.

Pongener, A., Mahajan, B.V.C. and Singh, H. 2011. Effect of different packaging films on storage life and quality of peach fruits under cold storage conditions. Indian J. Hortic., 68(2): 240-245.

Ranganna S. 1997. Handbook of analysis and quality control for fruit and vegetable products. $2^{\text {nd }}$ edn., Tata McGraw-Hill, New Delhi, India.

Sadasivam, S. and Manickam, A. 2005. Biochemical methods, Revised $2^{\text {nd }}$ edn., New Age Int. Publ., pp. 8-9.

Sandhu, S.S. and Singh, A.P. 2000. Effect of harvesting dates and individual seal packaging on the pear fruit $\mathrm{cv}$. Le Conte during cold storage. Haryana J. Hortic. Sci., 29: 48- 52.

Singh, A., Nath, A., Buragohain, J. and Deka, B.C. 2008. Quality and shelf life of strawberry fruits in different packages during storage. J. Food Sci. Technol., 45(5): 439-442.
Singh, B.P. and Narayan, C.K. 1999. The integrated approach for storage of mango. Indian J. Hortic., 56: 5-9.

Soliva, F.R.C. and Martin, B.O. 2003. Microbiological and biochemical changes in minimally processed freshcut Conference pears. Eur. Food Res. Technol., 217: 4-9.

Srivastava, R.P. and Kumar, S. 2002. Fruits and vegetables preservation - principles and practices. New York: Int. book Distr. Co., pp. 353-363.

Tijskens, L.M.M. and Vollebregt, H.M. 2003. Passive and semi-active modified atmosphere packaging of prickly pear cactus stems (Opuntis spp.). Acta Hortic., 604: 665-668.

Wills, R., Meglasson, B., Graham, D. and Joyce, D. 1998. Post-harvest: An Introduction to the Physiology and Handling of Fruits, Vegetables, and Ornamentals. CAB International, Wallingford, UK, pp. 262.

Zerbini, P.E. 2002. The quality of pear fruit. Acta Hortic., 596: 805-810.

\section{How to cite this article:}

Angami, T., S.R. Assumi, S. Baruah, A. Sen, B. Bam, A. Khatoon, B. Gurung and Kalita, H. 2017. A Study on the Quality Changes of Taktir Fruits (Garcinia lancifolia. Roxb) in Different Packages during Storage. Int.J.Curr.Microbiol.App.Sci. 6(8): 928-936. doi: https://doi.org/10.20546/ijcmas.2017.608.114 